\title{
Consolidated Democracy Advantage: \\ Political Instability and Sovereign Spreads in the EU
}

\author{
Josip Glaurdić ${ }^{1}$ \\ Université du Luxembourg \\ Christophe Lesschaeve \\ Université du Luxembourg \\ Maruška Vizek \\ Institute of Economics, Zagreb
}

\footnotetext{
${ }^{1}$ Corresponding author.

Address: Institute of Political Science UNIVERSITÉ DU LUXEMBOURG

11, porte des Sciences

L-4366 Esch-sur-Alzette
}

Emails: josip.glaurdic@uni.lu

christophe.lesschaeve@uni.lu

mvizek@eizg.hr 


\section{Consolidated Democracy Advantage: Political Instability and Sovereign Spreads in the EU}

We expose the way the market evaluates internal political risk and instability in democratic polities by analysing the determinants of sovereign spreads of EU member states over the course of the past two decades. Our analysis builds on the "democratic advantage" argument which suggests democracies enjoy preferential treatment on the international market of sovereign debt because of their better ability to make credible commitments. We suggest that, when it comes to the market's evaluation of internal political instability and risk in democratic polities, there actually exists a "consolidated democracy advantage". In times of political instability, older and more consolidated democracies pay less of a premium on their debt than their younger and less consolidated counterparts. In other words, the market indeed views the commitment of consolidated democracies with long track records of democratic competition and survival as something qualitatively different than the commitment of new democracies with short track records.

Keywords: sovereign debt; European Union; democratic consolidation; democratic advantage; political instability

Advanced economies hold $78 \%$ of the global mass of public debt (IMF 2018). When explaining the determinants of interactions between debtors and creditors, however, the relevant literature focuses disproportionally on developing nations. This is understandable as the attention of the financial world, the academic community, and the general public has been devoted to sovereign defaults (e.g. Cuadra and Sapriza, 2008; Eichler, 2014; Kohlscheen, 2010; Manasse et al., 2003; Saiegh, 2005; Savona and Vezzoli, 2015; Van Rijckeghem and Weder, 2009; Yue, 2010), which have been far more prevalent in the developing world. Until the Greek debt crisis in 2012, advanced economies in the post-WWII period simply did not default. There is, however, more to sovereign debt than default. Most obviously, governments pay vastly different interest rates on their debt which has dramatic impact on their economies and societies. Substantial differences in sovereign interest rates are important not only because different interest rates in the long run 
translate to hugely different national debt burdens, but also because these interest rates serve as a benchmark against which all other domestic borrowing is being priced. These interest rates are only partly based on the overarching market conditions or the so-called fundamentals of the countries' economic performance. As the last decade of European political and economic crises - from Greece and Italy to Spain and Ireland - has taught us, interest rates on sovereign debt go beyond the prevailing situation on the international market or the countries' economic performance to include the market's perceptions of the countries' political risk and instability. But do domestic political risk and instability matter differently in different social and institutional contexts? Intuitively and anecdotally, we tend to believe that they do.

When trying to find a rigorous answer to this question, however, the literature offers limited guidance, largely because attention has dominantly been paid to the difference in the market's evaluation of political risk between democratic and non-democratic economies. The debate here has been centred on the concept of "democratic advantage" (Schultz and Weingast, 2003, building on North and Weingast, 1989) - the preferential treatment democracies may enjoy on the international market of sovereign debt because of their supposedly better ability to make credible commitments. But what could account for the obvious differences in the way the market evaluates countries' internal political risk and instability among democracies - especially those which can be described as advanced economies? Considering the devastating effects of a string of sovereign debt crises which have shaken the foundations of the European project over the past ten years, finding an answer to this question is of paramount importance. 
International markets are obviously deeply interconnected, and global and regional dynamics are of critical importance in the determination of sovereign spreads (Malgouyres and MazetSonilhac, 2017). In this article, however, we focus on explaining the way the market evaluates domestic political risk and instability in democratic polities by analysing the determinants of sovereign spreads of EU member states over the course of the past two decades using an exhaustive quarterly panel database. Our analysis abandons the often (mis)used fixed effects approach in modelling panel data, and instead opts for a within-between specification based on Bell and Jones (2015). This allows us to extend our inquiry to internal contextual factors that we believe are affecting the market's evaluation of sovereign bonds of EU member states. The results of our analysis show that those internal contextual factors - particularly the maturity of a country's democratic consolidation - are indeed crucial for understanding the vast differences in the way sovereign spreads move in response to political events.

Despite a recent rise in populism and courting of non-democratic practices by a number of European governments, all EU member states in our sample have been typically considered consolidated democracies in the classical sense proposed by Linz and Stepan (1996) of democracy being "the only game in town". Nevertheless, our analysis leads us to conclude that the international markets' evaluation of domestic political instability and risk in European democracies is decisively influenced by what we term "consolidated democracy advantage". That is, all else equal, older and more consolidated democracies pay a smaller premium on sovereign debt in times of internal political instability than do younger and less consolidated democracies. Their longer records of successful democratic competition, as well as managing and surviving 
different periods of political instability - in other words, periods when the credibility of their commitment could conceivably be challenged - make a difference in their market reputations. The market's tolerance of political instability in mature democracies is, therefore, yet another piece of evidence in support of Hayek's (1960: 109) seminal proposition that the advantages of democracy "will show themselves only in the long run".

\section{Determinants of sovereign spreads: Beyond the economic fundamentals}

The study of the domestic determinants of sovereign spreads has been strongly influenced by analyses privileging the so-called economic or financial fundamentals as the principal explanatory variables. This literature can be traced back to the seminal paper by Edwards (1984), who modelled sovereign debt interest rates in developing countries as a function of the probability of country's default. The probability of default and sovereign debt interest rates in his model were placed in the context of external debt sustainability described by macroeconomic variables proxying countries' liquidity and solvency positions. The strongest proponents of this line of inquiry have most often been economists associated with international financial institutions like the International Monetary Fund and the European Central Bank. Their findings generally point in the direction of sovereign spreads being largely explainable by the countries' economic and fiscal performance, as well as by the prevailing context of the international financial markets. A somewhat simplistic - though not far off the mark - way to label this argumentation is "debt and deficit". The actual details of these analyses may vary, but the gist of their message - using samples of both emerging markets and developed EU member states - is that countries that lack the fiscal discipline (or have a history of lacking fiscal discipline) do not satisfy the external debt 
sustainability condition and thus pay higher premiums on their debt (Akitoby and Stratmann, 2006; Attinasi et al., 2009; Bernoth et al., 2004; Haque et al., 1998; Hauner et al., 2010; Nickel et al., 2011; Schuknecht et al., 2009). In this narrative, politics either takes a back seat or is by design non-existent because it is deemed as irrelevant or "difficult to code" (Hauner et al., 1998: 415).

A substantial body of scholarship, however, has convincingly demonstrated that politics should be taken seriously when identifying the determinants of the market's evaluation of sovereign debt. The principal variable of interest in this line of argumentation has been uncertainty. In modelling countries' internal political uncertainty, some studies have relied on indices created by experts (e.g. Baldacci et al., 2008; Bekaert et al., 2016; Eichler, 2014) and have found these to be solid predictors of investors' increased perception of risk in emerging markets. Those studies which have tried to unpack which factors lead to uncertainty could generally be divided into two camps: those which have related uncertainty to the various types of political institutions and those which have related uncertainty to political events. With regards to the latter, we can say that most attention has been paid to two questions. First, what is the effect of the timing of government or executive turnover on sovereign spreads? And second, what is the effect of the nature or the type of the political executive which is placed in power? Although this literature is highly diverse when it comes to the modelling of political variables and the sample size, type, and period it is concerned with, there is general agreement that the timing of executive turnover whether through elections or changes in relevant executive personnel - makes a significant contribution to the market's perception of uncertainty and risk. Changes of ministers of finance (Hallerberg and Wolff, 2008; Moser, 2007) and central bank governors (Moser and Dreher, 2010) 
have thus been found to increase sovereign debt premiums in both developed and developing economies, and elections - particularly contentious elections with either partisan turnover or turnover of incompetent incumbents - have been found to significantly affect not only sovereign spreads, but also overall market evaluation and performance also in both developed and developing economies (Bechtel, 2009; Bernhard and Leblang, 2002; Block and Vaaler, 2004; Eichler and Plaga, 2017; Pantzalis et al., 2000). When it comes to the nature or the type of the executive which is placed in power, there is overwhelming evidence that the market clearly prefers rightist governments regardless of the sample of countries used (Bechtel, 2009; Barta and Johnston, 2018; Fowler, 2006; Leblang and Mukherjee, 2005; Sattler, 2013; Vaaler et al., 2005; Vaaler et al., 2006), even though there has been little partisan difference in economic policy since the 1970s (Boix, 2000; Volkerink and de Haan, 2001) - just as there is significant evidence that the market penalises developing countries with divided and highly fragmented governments (Smaoui et al., 2017), likely due to the fact that more fragmented governments have been shown to lead to larger public sectors (Bawn and Rosenbluth, 2006), higher deficits (Elgie and McMenamin, 2008; Volkerink and de Haan, 2001), more debt (De Haan et al., 1999), and ultimately higher probability of default (Qian, 2010).

The analysis of the institutional sources of domestic instability and uncertainty, on the other hand, has been centred on the issue of credible commitment. The principal point of contention here has been whether democracies enjoy any sort of market advantage because representative institutions "make it easier for those with a stake in the repayment of debt to punish the sovereign in the event of default," as Schultz and Weingast (2003) have put it in their seminal 
study of several centuries of struggle for hegemony between liberal and autocratic competitors. Their proposition of a "democratic advantage" has been seriously scrutinised and the evidence thus far has been mixed. Archer et al. (2007) have found no evidence of a democratic advantage in bond ratings over the period of 1987-2003 for a sample of fifty developing countries. Similarly, in his analysis of a sample of eighty developing countries over the period 1971-1997, Saiegh (2005) has found that democracies did not enjoy any advantage in the pricing of their debt and that their "credible commitment" was non-existent as they were more likely to reschedule their debt. Others have, however, found the opposite to be true. Balkan's (1992) study of 33 developing nations in the period 1971-1984 has concluded that democratic countries did have a lower probability of default. Studying the sample of fifty developing nations in the period 19872003 from the Archer et al. (2007) study, Biglaiser et al. (2008) found that democratic nations particularly the poorest ones - did enjoy an advantage when it comes to attracting larger investments into their sovereign bonds. Similarly, Van Rijckeghem and Weder (2009), using a sample of 73 countries in the period 1974-2000, have demonstrated that having a parliamentary democracy with sufficiently strong economic fundamentals could almost guarantee the absence of default. The roots of the disagreement between the two strands of literature were probably best summed up by Beaulieu et al. (2012). They convincingly argued that most assessments of the democratic advantage have either ignored credit access as a source of democratic advantage (which inevitably led to selection bias in analysis) or have failed to account for the fact that economic development is endogenous to political institutions. Their study - analysing all countries for the period 1963-2008 - clearly showed that democracies indeed enjoy a double advantage: in credit access and in credit ratings. 
The literature on the determinants of sovereign spreads is sizeable and diverse. Nevertheless, it does not answer the primary questions of our interest - whether market evaluates political instability differently among democracies and why - for two reasons. First, most studies focus their attention on developing nations. And second, most studies model democracy in a binary yes/no manner. Democracy, however, is anything but binary. If Schultz and Weingast (2003) are correct - and we believe that they are - then there is good reason to believe that the market evaluates countries' credibility of commitment (especially during times of political instability when that credibility would presumably be under threat) on a sliding scale which is largely dependent on their democratic track record. In other words, getting commitment from a consolidated democracy with a long track record of successfully dealing with the ups and downs of democratic competition is not the same as getting it from a newer democracy with a short track record. We agree with Michael Tomz (2007): in the international market for sovereign bonds, reputations matter. What matters, however, are not only the reputations for orderly debt servicing, which is what Tomz's seminal study focused on, but also the reputations for successfully absorbing possible shocks from political instability. Credible commitment is a concept which is highly dependent on the strength of democratic institutions, and those institutions reach the necessary level of strength - in other words, democracy becomes consolidated - only as they go through the process of institutionalisation (Huntington 1968). The key factor in this process is time. As Acemoglu and Robinson have argued, a "democracy is consolidated if the set of institutions which characterise it endure through time." (Acemoglu and Robinson, 2005: 29) This leads us to the main proposition of our study: there exists a 
"consolidated democracy advantage" which manifests itself in older democracies paying lower premiums on their debt than newer democracies exactly when credible commitment could conceivably be under threat, i.e. during times of political instability.

\section{Data and estimation}

Our analysis relies on an extensive panel dataset with quarterly figures covering a string of both political and economic variables for all EU member states over the course of the past twenty years. ${ }^{1}$ We limit our study to EU member states partly due to the normative importance of answering our research question in the EU context, partly because we wish to control for a variety of contagion effects from countries' regional or institutional "peers", and partly because by limiting the sample on EU countries only, we ensure complete cross-country data comparability (Gray, 2013; Brooks et al., 2015). As Figure 1, which shows our data coverage, demonstrates, the panel we are working with is unbalanced. This is partly the case due to countries' different borrowing records and partly due to data availability. Considering our principal question of interest (whether the market evaluates political instability differently among democratic polities), the dependent variable in our analysis (Sovereign bond spread) is the spread on 10-year government bonds, which we define as a difference between a 10-year government bond yield of a given EU country and a corresponding yield on a German government bond, here expressed in percentage points.

\footnotetext{
${ }^{1}$ The only EU member states missing are Cyprus and Estonia which did not have outstanding long-term debt securities with a residual maturity of close to ten years during the period covered. (Eurostat 2018)
} 
Using the German government bond as a benchmark for spreads calculation means we effectively drop Germany from our sample. The US government bonds were a plausible alternative. However, that choice made less sense given that our sample contains only European countries and given recent developments with credit ratings of German and US sovereign bonds and yields levels. Since Germany is by far the largest European economy, its business cycle developments and structural changes make a substantial difference for the entire continent, while at the same time setting the benchmark for real economic convergence of the remaining EU countries. Therefore, using it as a benchmark makes it more justified from a purely economic standpoint. In addition, fiscal conservativism and strong fiscal results exhibited in Germany on the one hand and periodically unstable fiscal situation in the US on the other argues against using the US yield as a benchmark, especially after the US federal government was downgraded for the first time by the Standard \& Poor's in 2011, thus implying the US sovereign bonds lost their exceptional status of creditworthiness. The comparison of two countries' yields further reinforces our choice, as the level of German 10-year sovereign bond yields is persistently lower than the US yield throughout the analysed time period, with this gap increasing over time. Nevertheless, to assuage any concerns about our findings, we performed robustness checks using US government bonds as benchmark with minimal substantive difference in our results.

[Figure 1 about here]

Rather than relying on expert-created indices, which often suffer from a variety of methodological shortcomings, we model political instability using five different variables which 
have been commonly used in the literature as its suitable proxies. Table 1 lists all the variables used in our analysis together with their descriptive statistics, crucially for the raw data, as well as for the within and between transformations (of which more below). Our variable Minister of finance change thus captures the change in one member of the executive who has been consistently shown to have significant influence on the market's perception of economic policy stability - the minister of finance (Hallerberg and Wolff, 2008; Moser, 2007). Government fractionalisation represents the odds of two randomly selected members of the cabinet being from different parties - the assumption being that increased fractionalisation/fragmentation leads not only to higher deficits, debt, and ultimately spreads (Qian, 2010; Smaoui et al., 2017), but also to greater uncertainty and instability. Government majority represents the percentage of the legislature belonging to the ruling party or coalition. We are agnostic when it comes to expectations regarding this variable. On the one hand, lower majorities could lead to higher government instability because of higher probability of turnover and thus to higher spreads. On the other hand, however, lower majorities could suggest higher levels of collective responsibility which has been shown to depress bond spreads (Breen and McMenamin, 2013). Legislative election is a dummy variable which takes the value of 1 in the quarter when the legislative election takes place - elections generally being perceived by the market as times of uncertainty and instability (Block and Vaaler, 2004; Bussiere and Mulder, 2000). Left-wing government represents the 1-5 Schmidt index (Schmidt, 1992, 1996) of left-wing control of the government ministries, from the hegemony of right-wing and centre parties (1) through the balance of power between right-wing/centre parties and left-wing parties (3) to the hegemony of left-wing parties (5). As discussed above, a large body of research has demonstrated that the market clearly sees 
leftist governments as destabilising forces. All these variables have been adapted from the Comparative Political Data Set III developed at the University of Bern (Armingeon et al., 2014), which is on the annual level. They were tracked down in various historical and press records, correctly transformed onto quarterly level, and updated for the past several years which were unavailable in CPDS. Finally, we model our principal explanatory variable of interest Democratic consolidation as the number of consecutive years the country in question has been considered a full democracy, and we adapt and update it from the Polity IV project (Marshall et al., 2018). We are cognisant of the fact that consolidation and time are not the same thing and that the true empirical challenge lies in unpacking the concept of democratic consolidation and identifying its essence - whether in the strength of institutions, rule of law, respect for property rights, longterm outlook of policy makers, informal democratic norms, or myriad other things. Nevertheless, in an effort to remain parsimonious and objective, here we follow the findings of those before us who find the correlation between time and consolidation to be acceptably high (Acemoglu and Robinson, 2005; Svolik, 2008). Figure 2 shows the relationship between the average values for Democratic consolidation and Sovereign bond spread for all countries in our sample over the past two decades. The spreads' downward trend as the age of democracy increases is clear and highly indicative.

[Figure 2 about here]

No analysis of the market's pricing of domestic political instability would be credible without solid coverage of economic and financial fundamentals. All our models, therefore, also control for the 
economic factors that are known to be related to government bond spreads: GDP growth, inflation, domestic short-term interest rate, fiscal deficit, public debt, international reserves, and EMU membership. GDP growth rate represents short-term business cycle fluctuations, with better performance generally reducing country risk premium and thus dampening the government bond spread (Savona and Vezzoli, 2015). Inflation is the change in overall price level and is often used in empirical studies as a proxy for macroeconomic stability. Lower inflation is usually associated with lower sovereign spreads (Archer et al., 2007). As discussed above, fiscal balance and public debt - measuring the short-term fiscal stance and the overall level of public indebtedness - are variables that have been shown to be particularly important in the empirical studies focused on the economic fundamentals. As government bonds are instruments used by governments to finance public spending, a favourable fiscal stance reflected in lower fiscal deficits or even surpluses along with more moderate levels of public indebtedness have been shown to generally reduce government bond spreads. Domestic interest rates, on the other hand, reflect both the monetary policy position and the short-term cost of financing in a given economy. To achieve cross-country comparability, wherever possible, we used the quarterly averages of 1-month money market rates. International reserves represent the amount of assets accumulated by the central bank to ensure external liquidity needed to stabilize sudden currency swings and alleviate current account crises. Higher accumulation of international reserves is perceived as a sign of macroeconomic stability, which reduces country's risk premium. Finally, we use dummies for EMU membership, as EMU membership has been shown to be a successful mechanism of signalling (the enforcement of) fiscal discipline which has dampened the member states' premium payments on their sovereign debt (Hallerberg and Wolff, 2008). We could have 
arguably also used some form of variable capturing EU membership (Gray, 2013), but we feel EMU membership, ensuing after the successful fulfilment of the Maastricht criteria focused on enforcing fiscal discipline, captures more closely the reputational benefits for new member states on the international market and is more appropriate considering our sample and the period we cover. Robustness checks with dummies for EU membership show little substantive change in results. As Table 1 outlines, fiscal balance, public debt and international reserves are expressed as percentages of GDP, while GDP growth, inflation and domestic interest rates are expressed as percentages. All economic controls have been seasonally adjusted and have been acquired either from Eurostat (2018) or from the International Financial Statistics database published by the IMF (2018).

[Table 1 about here]

Because we use panel data, the variation is situated on two levels, within countries (and thus across time) and between countries. For instance, government bond spread at a particular point in time might be related to whether the government just changed its minister of finance, and it might be related to the overall stability of the position of the minister of finance, i.e. how many times the post of minister of finance changed hands over a certain timespan. Two countries that both change their finance minister at the same time might still experience different levels of government bond spread if, ceteris paribus, in one country such a change happens more frequently than in the other. A regular analytical approach relies on models with independent variables that conflate the within and between sources of variation, which leads to interpretative 
difficulties and oftentimes erroneous conclusions. A common solution to this problem is the use of a fixed effects (FE) approach, in which the variation between the cases is removed. However, this approach is clearly problematic because the variation between the cases - particularly in contextual variables which either change slowly or not at all - should be of interest when explaining the relation between the independent and dependent variable (Kohlscheen, 2010; Rommerskirchen, 2015).

In this article, we seek to supersede the fixed-effects approach and analyse the sources of both the between and the within variation of our dependent variable, government bond spread, by relying on the within-between (WB) approach, recently popularised by Bell and Jones (2015) who followed and perfected the methodological guidelines first introduced by Mundlak (1978). In doing so, we aim to improve our understanding of how government bond spread changes over time within countries and why government bond spreads vary between countries. The withinbetween approach entails two transformations of each independent variable, resulting in two separate versions of it, one capturing its within-relation and the other its between-relation with the dependent variable. To capture the between-effects, the variable should no longer vary over time, but only between countries. This is achieved by calculating its mean for every higher-level entity. Capturing the within-effects requires the opposite, removing any between-country differences. The within effects-variable is therefore calculated by subtracting from the value the higher-level entity's mean, thereby removing any between-effects from the variable - which is equivalent to standard FE estimation. In other words, the between-effects are captured by calculating the country mean and the within-effects are captured by mean-centring the variable 
on the country mean. In essence, the between-effect captures the general reputation that a country has built over time. For instance, when a country is frequently led by a left-wing government, it develops a reputation for being more left-wing. This reputation is expected to be taken into account by investors regardless of whether the government is right- or left-wing at a given time. The within-effect captures what exactly happens when a government's ideology changes from left to right (or vice versa), regardless of how often governments in that country are left- or right-wing. To be more specific, the Bell and Jones (2015) WB equation includes both within and between effects of the explanatory variable $x_{t j}$ on $y_{t j}$ (in our case sovereign bond spread):

$$
y_{t j}=\beta_{0}+\beta_{1}\left(x_{t j}-\bar{x}_{j}\right)+\beta_{2} \bar{x}_{j}+\beta_{3} z_{j}+\gamma_{t}+\left(u_{j}+e_{t j}\right)
$$

where $t$ in our case represents time/quarters (within-entity units), and $j$ represents countries (between-entity units). In this equation, $x_{t j}$ is the time-variant variable observed on a withinentity level, while $\bar{x}_{j}$ is the time-invariant (between-entity) component. $z_{j}$ represents the other time-invariant covariates, while $u_{j}$ is the between-entity error and $e_{t j}$ is the within-entity error. It is useful to note that the WB approach expressed in this way allows us to model endogeneity - which often plagues country-level empirical studies - explicitly, because it accounts for the between effect by including the higher-level mean. For instance, if we were to explain sovereign bond spread solely by the left- or right-wing composition of the government at time $t$ (the withineffect), our analyses could potentially overestimate the effect of the independent variable on the dependent variable as both are likely related to the general ideological preference in a country indicated by a frequent occurrence of left- or right-wing governments. This latter effect is accounted for by including the between-effect in the models. The WB approach thus also avoids 
the within-effect omitted variable bias just like the FE approach does. Coefficient $\beta_{1}$ represents the within effect, while $\beta_{2}$ is the between effect of $x_{t j}$ on $y_{t j}$. In other words, the estimated coefficient $\beta_{1}$ is the same if calculated using FE estimation, which means that the within effects reported in the WB estimation are equivalent to those obtained through FE estimation. Government bond spreads are obviously also affected by time-specific events of continental or even global importance. For instance, a decade ago the European government bond market was heavily affected by the sovereign debt crisis. The relation between such events and government bond spreads is, however, beyond the scope of this paper. Therefore, we control for such events and general time-effects by including time (quarter) dummies to all our models, expressed above as $\gamma_{t}$. Further details of the method's benefits and shortcomings and its application in a similar context can be seen in Glaurdić and Vuković (2017).

\section{Results: Political instability and the consolidated democracy advantage}

Table 2 presents the results of our panel analysis of the market's evaluation of political instability in EU member states over the course of the past two decades. The table shows the results for two models - one capturing the direct effects of our principal explanatory variables of interest, and the other modelling our main research question, i.e. the impact of democratic consolidation on the market's evaluation of political instability. The upper part of the table shows the within effects which are, once again, identical to the results one would obtain with fixed effects estimation. The lower part of the table, on the other hand, shows the between effects. Both models also include the aforementioned economic/financial controls, but their coefficients are omitted from the tables for ease of presentation. Full model results are available in the online 
appendix, and it is worth noting that the findings regarding the so-called economic fundamentals (particularly regarding public debt and domestic interest rates) are generally in line with the literature, with one important caveat which highlights the usefulness of the within-between approach: rising GDP lowers spreads on the within level, but on the between level we see that countries which on average have higher rates of GDP growth also have higher spreads. Taking into account that less developed new member states of the EU have been on the nominal economic convergence path characterised by higher rates of GDP growth when compared to their developed EU counterparts, this finding obviously makes sense. Here we should also mention that we conducted a number of robustness checks, none of which presented any challenge to our findings. As already noted, we performed our analyses using US government bonds as benchmarks and using EU instead of EMU membership as a proxy for the benefits of association with the project of European integration. We also tested whether our findings were primarily the story of Eastern vs. Western Europe by including a dummy for the former Soviet bloc countries; we excluded the United Kingdom from our analyses considering the exceptional longevity of its democracy; and we included a variable measuring time since last default in order to validate our principal proposition in competition with Tomz's (2007) thesis that what the market cares about is a history of orderly debt servicing. Our findings were substantively very similar to the reported results. ${ }^{2}$

[Table 2 about here]

\footnotetext{
${ }^{2}$ We also tested whether the data is stationary using the Im-Pesaran-Shin unit-root test (for unbalanced data). The null-hypothesis in the test was rejected, indicating that the data does not contain a unit root $(p<0.001)$ and our findings are not driven by spurious correlation.
} 
It is immediately apparent from the figures presented in Table 2 that political considerations play a significant role in the market's evaluation of sovereign spreads of EU member states. Looking at model 1 , we can see that all political variables reach at least the $5 \%$ significance level in either the within or the between segment of the analysis. Most significantly for our theoretical propositions, consolidated democracies definitely enjoy a market advantage. The average value of Democratic consolidation for the countries in our sample is 43 years. Countries with one standard deviation worth of additional years of democratic consolidation (30.23) enjoy spreads that are 0.6 percentage points lower. Considering that the standard deviation for spreads in this sample is 2.16 percentage points - this is a substantively sizeable effect.

Substantive importance of other political variables is also considerable. If a country changes its minister of finance, its spread in that quarter increases by, on average, a full percentage point. Countries in our sample change ministers of finance on average every ten quarters (since the mean of this variable for the between transformation is 0.10$)$. The between transformation tells us that a country that changes its ministers of finance on average one full standard deviation (which is, as seen in Table 1, equal to 0.04 ) less often than other countries in the sample, has spreads which are 0.2 percentage points lower than the average. These are also substantively sizeable effects, which accentuate the importance of turnover in the political executive (Hallerberg and Wolff, 2008; Moser, 2007).

Similarly, if a country's government shifts by one standard deviation (1.40 in the within transformation) towards the left on the left-right ideological Schmidt scale, its spread increases 
by about 0.18 percentage points. The between effect of ideological orientation of the government is somewhat smaller: for countries which on average have governments that are one standard deviation more to the left than the sample mean (0.58 in the between transformation), the average spread is 0.12 percentage points higher. In line with the rest of the literature, we confirm the market's preference for rightist governments even in the EU context and long after the 1970s and the height of ideological differences in economic policies between the left and right parties.

Our findings regarding the effect of the size of the governmental parliamentary majority support the analysis of Breen and McMenamin (2013) who suggest that higher collective responsibility (lower government majorities - particularly those that go into minority government territory could be seen as embodying higher collective responsibility) is viewed positively by the market. Our model shows that higher governmental majorities lead to higher spreads on both the within and the between levels. If a government increases its majority by one standard deviation (0.07), its bond spread increases by nearly 0.3 percentage points. The effect is somewhat smaller on the between level: for countries which have governmental majorities about one standard deviation higher than the sample mean (0.06), bond spreads are higher by about 0.12 percentage points.

The benefits of the within-between approach are clearly demonstrated when we look at the effects of the Legislative election and Government fractionalisation variables. Legislative elections have no statistically significant effect on the within level. In other words, in the quarter when it has a legislative election, a country does not necessarily experience a market backlash in 
the form of stricter country risk evaluation. However, countries that generally have more legislative elections do have to pay higher premiums on sovereign bonds. Countries in our sample on average have legislative elections every 14 quarters (since the mean of Legislative election is equal to 0.07$)$. If they were to have legislative elections one standard deviation (0.01) more often, their government bond spread would on average be 0.4 percentage points higher. The difference between the within and between findings is even starker when we look at Government fractionalisation. Our model 1 suggests that if a country's government fractionalisation increases by one standard deviation in a given quarter, then so does its bond spread by about 0.09 percentage points - a substantively small, but statistically significant result. On the other hand, the between effects portion of the analysis suggests that countries which have on average higher government fractionalisation actually have lower spreads. A one standard deviation higher fractionalisation leads to 0.27 percentage points lower spreads. When it comes to fractionalisation, we must therefore distinguish between what we may label as historical and immediate effects. Countries with a history of coalition governments (which implies higher levels of collective responsibility) in the European context have been viewed favourably by the market, although the market's immediate response to an increase in government fractionalisation has been negative.

The essence of our theoretical proposition is, however, tested by Model 2. We proposed that there exists a "consolidated democracy advantage" where more consolidated, older democracies enjoy a market advantage because they do not have to pay (as high of) a premium on their debt in times of political instability. As the coefficients for eight out of ten relevant interactions in 
Model 2 show, that is definitely the case. The only two instances which do not reach statistical significance are the within effects of the interactions of Democratic consolidation with Left-wing government and Democratic consolidation with Legislative elections. In other words, the level of consolidation of a democracy has no bearing on the way the market interprets changes in the ideological makeup of its government or the occurrence of a legislative election (though we should note that the interaction between Democratic consolidation and Left-wing government becomes significant and in the expected direction on the within level when we exclude the United Kingdom from our sample - likely the effect of the Labour government presiding over a long period of stability and low spreads). On the other hand, the level of consolidation of a democracy has a bearing on the way the market interprets other forms of potentially destabilising political events.

If we stay on the within level of analysis, we can see that the level of democratic consolidation dampens the rise of spreads in case of a change in the minister of finance, rise in the level of government fractionalisation, or an increase in the size of the government's parliamentary majority. The importance of the conditional effect of democratic consolidation on the five political variables is even more evident on the between level of analysis. Politically unstable consolidated democracies in the EU pay less of a premium on debt than their equally unstable, but less consolidated, counterparts. That is the case for all five political variables we test. Democratic consolidation lowers the positive impact on spreads of: repeated changes of the minister of finance, higher levels of government fractionalisation, larger government majorities, more frequent legislative elections, and more left-wing governments. We present our Model 2 
findings graphically in Figures 3-7 which show the within and between effects of our five political variables on predicted sovereign spread values, conditional on the level of democratic consolidation. In each figure, the graph on the left shows the predicted values of sovereign bond spreads across different levels of democratic consolidation if we vary the political variable of our interest by one standard deviation above and below the mean (except for the Minister of finance change and Legislative election which are binary variables) in the within portion of our analysis while keeping all other variables at their mean. The graphs on the right present the same for the between portion of our analysis.

[Figures 3-7 about here]

These figures enable us to paint a much more nuanced picture about the impact of democratic consolidation on the market's perception of political instability and risk. Figure 3 clearly shows the advantage more consolidated democracies enjoy at times of change of minister of finance. Completely new democracies pay a nearly 2 percentage points higher premium on their bonds in the quarter when they change their minister of finance, whereas that gap narrows to about one point at the mean value (46.59) of Democratic consolidation. The right-hand side of the figure is arguably more interesting. It shows that younger democracies which change ministers of finance more often than the average pay a premium on their sovereign debt. This effect, however, reaches zero at about the 30-year mark for Democratic consolidation and thereafter actually turns negative. In other words, for democracies younger than about 30 years on average in our sample (i.e. post-communist Eastern Europe plus Spain, Portugal, and Greece), frequent 
ministerial changes increase spreads, whereas for older democracies of Western Europe they decrease spreads.

Figure 4 also provides an important wrinkle to our previously discussed story about historical and immediate effects of government fractionalisation on the market's perception of political instability. The left-hand side of the graph shows that increases in government fractionalisation indeed lead to higher spreads. Crucially, however, this effect completely peters out and eventually flips at about the 70-year mark in democratic consolidation - right around the average age of most West European deeply consolidated democracies. The right-hand side of the figure tells a similar story. Younger democracies which have a higher than average government fractionalisation pay a higher bond premium. This effect disappears at around the 30-year mark and thereafter flips in the opposite direction. So, whereas our model 1 was suggesting the effects of Government fractionalisation in the within portion of analysis were opposite to those in the between portion of analysis, model 2 suggests those effects - when we take into account Democratic consolidation - are actually very similar.

Figures 5-7 provide us with the same type of graphical presentation of model 2 results for the variables Government majority, Legislative election, and Left-wing government. Two things are arguably most notable in these three figures. First, the between effects of Legislative election on sovereign bond spreads clearly show the dramatic advantage consolidated democracies enjoy when it comes to the average frequency of legislative elections. Unconsolidated democracies which have legislative elections more often than the average pay a steep premium on their 
sovereign debt compared to unconsolidated democracies which have legislative elections less often than the average. This effect, however, disappears around the 65-year mark. And second, the between effects of Left-wing government on sovereign bond spreads show that it is less consolidated democracies which get penalised for having left-wing governments more often than average, whereas more consolidated democracies - after about the 40-year mark - get rewarded. In other words, the market perceives left-wing governments as the bearers of political risk in younger democracies and as the bearers of political stability in older democracies - or, we should say, at least in the older democracies in our sample, with the Scandinavian social democrats and Blair's Labour Party presiding over long periods of prosperity, stability, and low bond spreads.

\section{Conclusions}

This article was written with three goals in mind. Our first goal was methodological, and it was an answer to those who have been rightfully critical of the literature's excessive reliance on fixed effects estimation (Kohlscheen, 2010; Rommerskirchen, 2015). We wanted to further popularise the benefits of the within-between specification (Bell and Jones, 2015) and to thereby help bring clarity to our understanding of the true impact of political instability on sovereign debt spreads. Second, we wanted to contribute to the growing body of work which has demonstrated that political considerations should be taken seriously when identifying the determinants of the market's evaluation of sovereign debt. In our view, privileging the so-called economic and financial "fundamentals" in the analyses of sovereign debt spreads is not a research strategy that yields reliable results. Finally, and most importantly, we wanted to demonstrate that domestic 
political risk and instability matter differently in different contexts - even when one examines a group of advanced democratic economies such as EU member states. To be more specific, we wanted to demonstrate that there exists what we call a "consolidated democracy advantage" in the way the market evaluates internal political risk and instability. At the root of all calculations of debt premiums is credible commitment and we wanted to test whether the market viewed the commitment of consolidated democracies with long track records of more or less successful democratic competition as something qualitatively different than the commitment of new democracies with short track records.

We believe our article fulfilled all three of those goals. The within-between approach has shown its usefulness by enabling us to make nuanced within vs. between distinctions in the effects of various political variables on sovereign bond spreads. Our analysis furthermore clearly demonstrated that, when we talk about the determinants of sovereign debt spreads, politics matters. And finally, we showed that there indeed exists a "consolidated democracy advantage" in the way the market evaluates domestic political instability and risk. Older and more consolidated democracies pay less of a premium on their debt than their younger and less consolidated counterparts, and this difference is particularly pronounced during times of political instability when the credibility of their commitment could conceivably be most in question. In other words, the market indeed views the commitment of consolidated democracies with long track records of successfully dealing with the ups and downs of democratic competition as something qualitatively different - i.e. more credible - than the commitment of younger democracies with short track records. Reputations matter - not only reputations for orderly debt 
servicing, but also reputations for successfully absorbing possible shocks from internal political instability. This proposition builds on the classical argument of the democratic advantage (North and Weingast, 1989; Schultz and Weingast, 2003) by identifying one critical condition - time. It is time that is needed for the democratic institutions to reach the level of maturity and stability necessary to make the state's commitment credible in the eyes of the market. Time that exactly those states which are often the most vulnerable on the international market do not have.

As insightful as our study may be, it also opens a number of questions that still need to be answered by the scholarly community. We establish that a "consolidated democracy advantage" exists by using EU member states as our sample. This finding needs to be tested on a broader set of cases. More importantly, significant effort needs to be devoted to better identifying the exact causes of this advantage. Our proposal is that time is a sufficiently strong proxy for democratic consolidation which can capture the essence of a country's appeal in the eyes of international investors. Ultimately, however, we need to decompose that proxy and establish whether the root causes of a "consolidated democracy advantage" lay in longer records of dealing with political instability, better institutions, stronger rule of law, better protection of property rights, something else altogether, or all of the above. That is a challenging task as many of these things are so closely connected and deeply intertwined. Nevertheless, we must complete it if we are to fully understand the political economy of international debt in the contemporary (democratic) world. 


\section{References}

Acemoglu, D. and Robinson, J.A. (2005) Economic origins of dictatorship and democracy. Cambridge: Cambridge University Press.

Akitoby, B. and Stratmann, T. (2006) Fiscal policy and financial markets. IMF Working Paper WP/06/16.

Archer, C.C., Biglaiser, G., and DeRouen, K. (2007) Sovereign bonds and the "democratic advantage": Does regime type affect credit rating agency ratings in the developing world? International Organization 61 (2): 341-365.

Armingeon, K., Knöpfel, L., Weisstanner D. and Engler, S. (2014) Comparative political data set III 1990-2012. Bern: Institute of Political Science, University of Bern.

Attinasi, M., Checherita, C. and Nickel, C. (2009) What explains the surge in euro area sovereign spreads during the financial crisis of 2007-09? European Central Bank Working Paper 1131.

Baldacci, E., Gupta, S. and Mati, A. (2008) Is it (still) mostly fiscal? Determinants of sovereign spreads in emerging markets. IMF Working Paper WP/08/259.

Balkan, E. (1992) Political instability, country risk and probability of default. Applied Economics 24: 999-1008.

Barta, Z. and Johnston, A. (2018) Rating politics? Partisan discrimination in credit ratings in developed economies. Comparative Political Studies, 51(5): 587-620.

Bawn, K. and Rosenbluth, F. (2006) Short versus long coalitions: Electoral accountability and the size of the public sector. American Journal of Political Science 50(2): 251-265. 
Beaulieu, E., Cox, G.W. and Saiegh, S. (2012) Sovereign debt and regime type: Reconsidering the democratic advantage. International Organization 66 (4): 709-38.

Bechtel, M.M. (2009) The political sources of systematic investment risk: Lessons from a consensus democracy. Journal of Politics 71: 661-677.

Bekaert, G., Harvey, C.R. Lundblad, C.T. and Siegel, S. (2016) Political risk and international valuation. Journal of Corporate Finance 37: 1-23.

Bell, A., and Jones, K. (2015) Explaining fixed effects: Random effects modelling of time-series cross-sectional and panel data. Political Science Research and Methods 3(1): 133-153.

Bernhard, W. and Leblang, D. (2002) Democratic processes, political risk, and foreign exchange markets. American Journal of Political Science 46(2): 316-333.

Bernoth,K., von Hagen, J., and Schuknecht, L. (2004) Sovereign risk premia in the European government bond market. European Central Bank Working Paper 369.

Biglaiser, G., Hicks, B., and Huggins, C. (2008) Sovereign bond ratings and the democratic advantage: Portfolio investment in the developing world. Comparative Political Studies 41: 1092-1116

Block, S.A., and Vaaler, P.M. (2004) The price of democracy: Sovereign risk ratings, bond spreads and political business cycles in developing countries. Journal of International Money and Finance 23(6): 917-946.

Boix, C. (2000) Partisan governments, the international economy, and macroeconomic policies in advanced nations, 1960-93. World Politics 53: 38-73.

Breen, M. and McMenamin I. (2013) Political institutions, credible commitment, and sovereign debt in advanced economies. International Studies Quarterly 57: 842-854. 
Brooks, S., Cunha, R. and Mosley, L. (2015) Categories, creditworthiness, and contagion: How investors' shortcuts affect sovereign debt markets. International Studies Quarterly 59(3): $587-601$.

Bussiere, M. and Mulder, C. (2000) Political instability and economic vulnerability. International Journal of Finance and Economics 5(4): 309-330.

Cuadra, G. and Sapriza, H. (2008) Sovereign default, interest rates and political uncertainty in emerging markets. Journal of International Economics 76: 78-88.

De Haan, J., Sturm, J.E. and Beekhuis, G. (1999) The weak government thesis: Some new evidence. Public Choice 101(3-4): 163-176.

Edwards, S. (1984) LDC foreign borrowing and default risk: An empirical investigation 1976-80. American Economic Review 74: 726-734.

Eichler, S. (2014) The political determinants of sovereign bond yield spreads. Journal of International Money and Finance 46(C): 82-103.

Eichler, S. and Plaga, T. (2017) The economic performance of the government and the resolution of uncertainty in sovereign bond markets around national elections. Working paper.

Elgie, R., and McMenamin, I. (2008) Political fragmentation, fiscal deficits and political institutionalisation. Public Choice 136: 255-267.

Eurostat. (2018) Available at ec.europa.eu/eurostat/data/database.

Fowler, J.H. (2006) Elections and markets: The effect of partisanship, policy risk, and electoral margins on the economy. Journal of Politics 68(1): 89-103. 
Glaurdić, J. and Vuković, V. (2017) Granting votes: Exposing the political bias of intergovernmental grants using the within-between specification for panel data. Public Choice 171(1-2): 223-241.

Gray, J. (2013) The Company States Keep: International Economic Organizations and Investor Perceptions. Cambridge, UK: Cambridge University Press.

Hallerberg, M. and Wolff, G. (2008) Fiscal institutions, fiscal policy and sovereign risk premia in EMU Public Choice 136: 279-396.

Haque, N.U., Nelson, M. and Mathieson, D.J. (1998) The relative importance of political and economic variables in creditworthiness ratings. IMF Working Paper WP/98/46.

Hauner, D., Jonas, J. and Singh Kumar, M. (2010) Sovereign risk: Are the EU's new member states different? Oxford Bulletin of Economics and Statistics 72(4): 411-427.

Hayek, F. (1960) The constitution of liberty. Chicago, IL: University of Chicago Press.

Huntington, S. (1968) Political order in changing societies. New Haven, CT: Yale University Press.

IMF. (2018) International financial statistics. Available at: http://data.imf.org/

Kohlscheen, E. (2010) Sovereign risk: constitutions rule. Oxford Economic Papers 62: 62-85.

Leblang, D., and Mukherjee, B. (2005) Government partisanship, elections, and the stock market: Examining American and British stock returns, 1930-2000. American Journal of Political Science 49: 780-802.

Linz, J. and Stepan, A. (1996) Toward consolidated democracies. Journal of Democracy 7(2): 1433.

Malgouyres, C. and Mazet-Sonilhac, C. (2018) Political uncertainty, risk of Frexit and European sovereign spreads. Applied Economics Letters 25(14): 1004-1009. 
Manasse, P., Roubini, N. and Schimmelpfennig, A. (2003) Predicting sovereign debt crisis. IMF Working Paper WP/03/221

Marshall, M.G., Gurr, T.R., Jaggers, K. (2018) Polity IV project: Political regime characteristics and transitions, 1800-2016. Available at www.systemicpeace.org/inscrdata.html

Moser, C. (2007) The impact of political risk on sovereign bond spreads - evidence from Latin America. Proceedings of the German Development Economics Conference, Göttingen 2007. Verein für Sozialpolitik, Research Committee Development Economics, No. 24.

Moser, C., and Dreher, A. (2010) Do markets care about central bank governor changes? Journal of Money, Credit and Banking 42(8): 1589-1612.

Mundlak, Y. (1978) On the pooling of time series and cross section data. Econometrica 46(1): $69-85$.

Nickel, C., Rother, P. and Ruelke, J.-C. (2011) Fiscal variables and bond spreads - evidence from Eastern European countries and Turkey. Applied Financial Economics 21(17): 1291-1307.

North, D.C. and Weingast, B.R. (1989) Constitutions and commitment: The evolution of institutions governing public choice in seventeenth-century England. Journal of Economic History 49(4): 803-832.

Pantzalis, C., Stangeland, D. and Turtle, H. (2000) Political elections and the resolution of uncertainty: The international evidence. Journal of Banking and Finance 24: 1575-1604.

Qian, R. (2010) Why do some countries default more often than others? The role of institutions. Working paper.

Rommerskirchen, C. (2015) Fiscal rules, fiscal outcomes and financial market behavior. European Journal of Political Research 54: 836-847. 
Saiegh, S.M. (2005) Do countries have a "democratic advantage"? Political institutions, multilateral agencies, and sovereign borrowing. Comparative Political Studies 38(4): 366387.

Sattler, T. (2013) Do markets punish left governments? Journal of Politics 75(2): 343-356.

Savona, R. and Vezzoli, M. (2015) Fitting and forecasting sovereign defaults using multiple risk signals. Oxford Bulletin of Economics and Statistics 77(1): 66-92.

Schmidt, M.G. (1992) Regierungen: Parteipolitische Zusammensetzung. In Lexikon der Politik, Band 3. Die westlichen Länder, ed. Schmidt, M.G. 393-400. München: C.H. Beck.

Schmidt, M.G. (1996) When parties matter: A review of the possibilities and limits of partisan influence on public policy. European Journal of Political Research 30: 155-183.

Schuknecht, L., von Hagen, J. and Wolswijk, G. (2009) Government risk premiums in the bond market: EMU and Canada. European Journal of Political Economy 25: 371-384.

Schultz, K. and Weingast, B. (2003) The democratic advantage. International Organization 57(1): $3-42$.

Smaoui, H., Boubakri, N. and Cosset, J.-C. (2017) The politics of sovereign credit spreads. Emerging Markets Finance and Trade 53(8): 1894-1922.

Svolik, M. (2008) Authoritarian reversals and democratic consolidation. American Political Science Review 102(2): 153-168.

Tomz, M. (2007) Reputation and International Cooperation: Sovereign Debt across Three Centuries. Princeton, NJ: Princeton University Press. 
Vaaler, P.M., Schrage, B.N. and Block, S.A. (2005) Counting the investor vote: Political business cycle effects on sovereign bond spreads in developing countries. Journal of International Business Studies 36: 62-88.

Vaaler, P.M., Schrage, B.N. and Block, S.A. (2006) Elections, opportunism, partisanship and sovereign ratings in developing countries. Review of Development Economics 10(1): 154170.

Van Rijckeghem, C. and Weder, B. (2009) Political institutions and debt crises. Public Choice 138(3/4): 387-408.

Volkerink, B. and de Haan,J. (2001) Fragmented government effects on fiscal policy: New evidence. Public Choice 109(3-4): 221-242.

Yue, V. Z. (2010) Sovereign default and debt renegotiation. Journal of International Economics 80: 176-187.

\section{Authors' biographies:}

Josip Glaurdić is an Associate Professor of Political Science at the University of Luxembourg and Principal Investigator of the project ELWar - Electoral Legacies of War (ERC Starting Grant 714589).

Christophe Lesschaeve received his PhD in 2017 from the University of Antwerp. He is a postdoctoral researcher at the University of Luxembourg. His research interests include political representation, opinion congruence, and voting behaviour in postwar societies.

Maruška Vizek is the director and research fellow of the Institute of Economics, Zagreb. Her fields of interest include international finance, applied international macroeconomics, real estate economics, and business cycle research.

\section{Acknowledgement:}

This work was supported by the Croatian Science Foundation (HZZ) under the project 1356:

"Economic, statistical and political aspects of sovereign bond markets" 
Figure 1. Data coverage

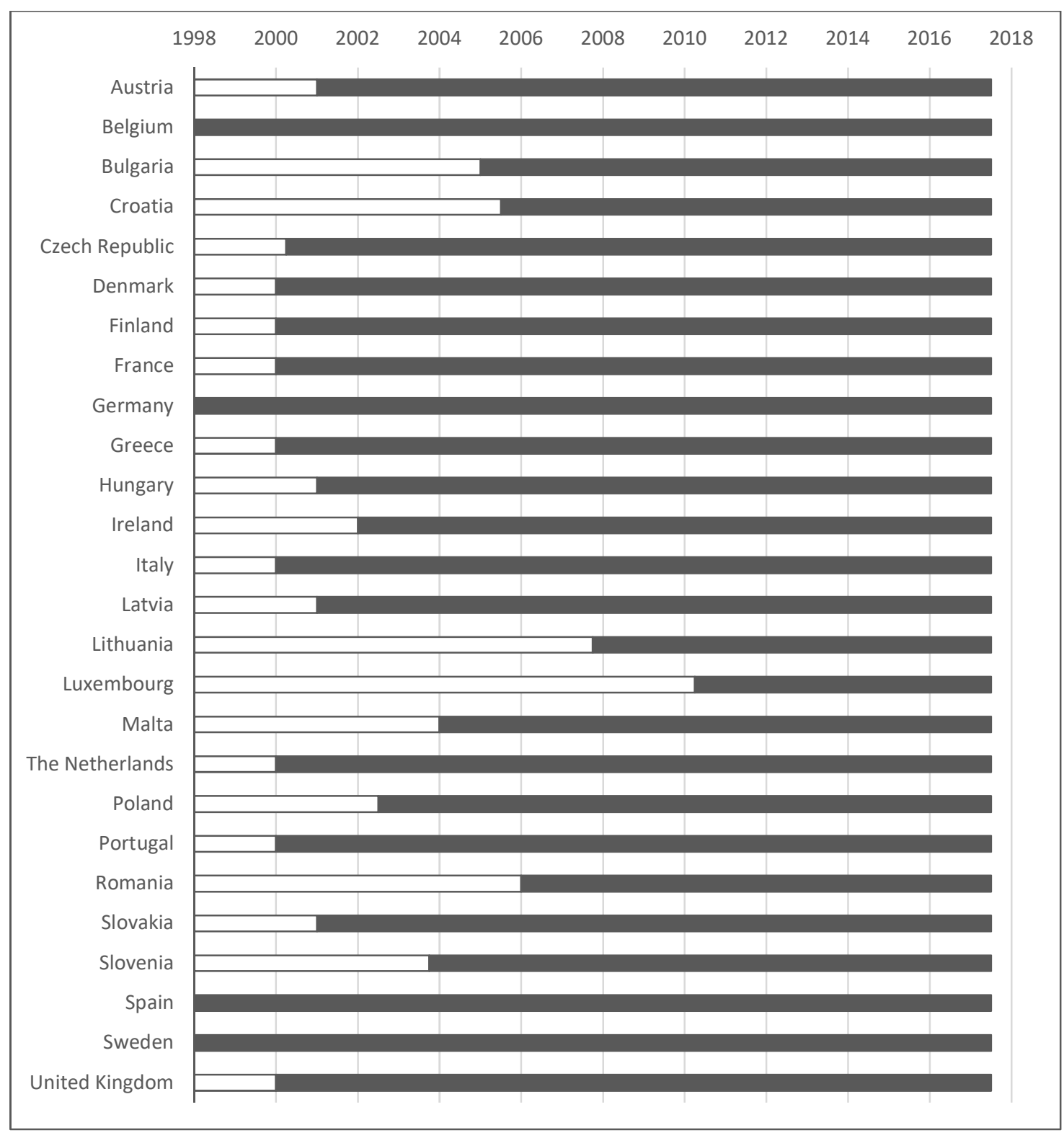


Figure 2. Democratic consolidation and sovereign bond spreads

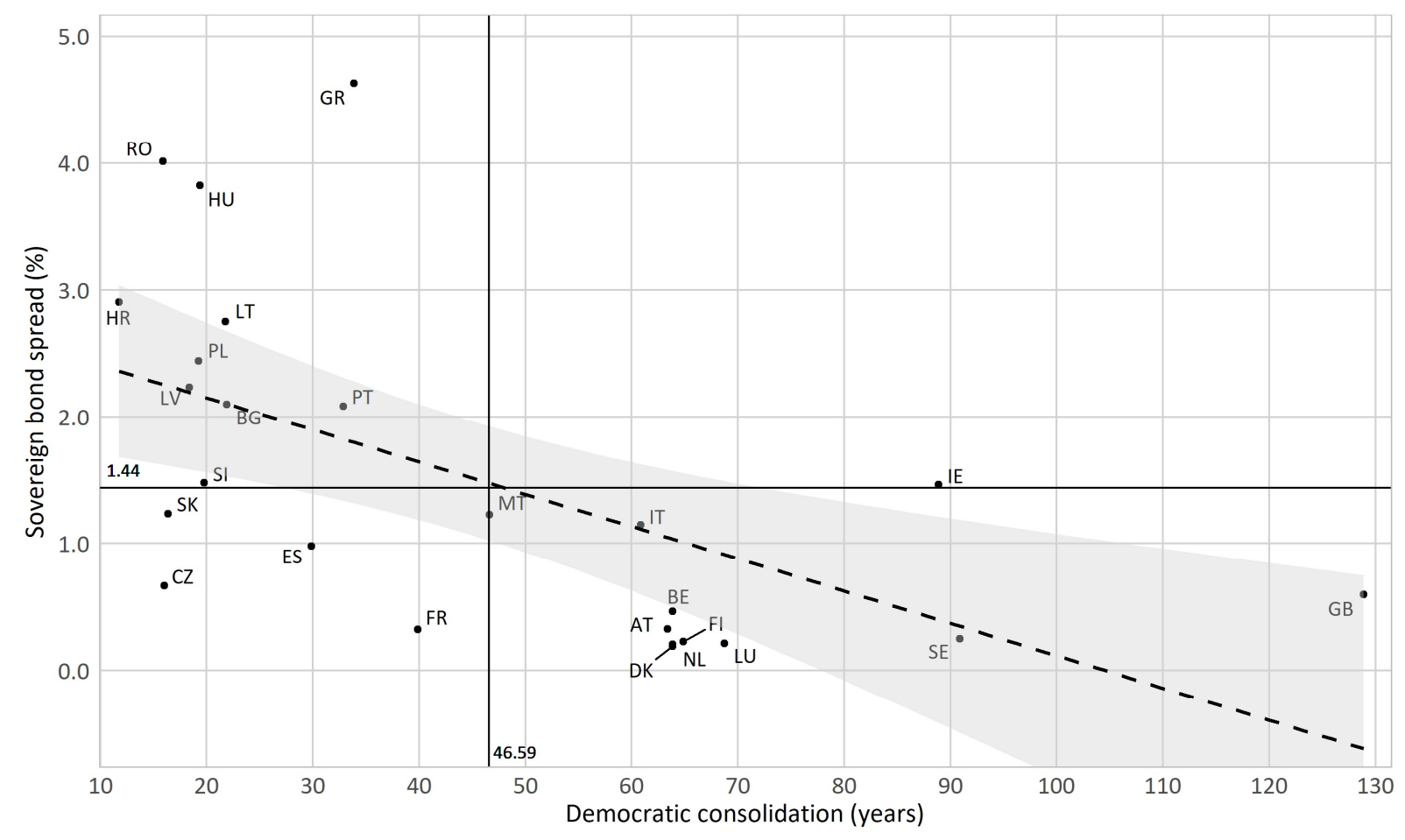


Table 1. Overview of all variables

\begin{tabular}{|c|c|c|c|c|c|c|c|c|c|c|c|c|}
\hline \multirow[b]{2}{*}{ Variable } & \multicolumn{4}{|c|}{ Raw data } & \multicolumn{4}{|c|}{ Within transformation } & \multicolumn{4}{|c|}{ Between transformation } \\
\hline & Mean & SD & Min. & Max. & Mean & SD & Min. & Max. & Mean & SD & Min. & Max. \\
\hline Sovereign bond spread (\%) & 1.44 & 2.16 & -0.31 & 23.98 & & & & & & & & \\
\hline Minister of finance change & 0.10 & 0.30 & 0 & 1 & 0.00 & 0.30 & -0.18 & 0.99 & 0.10 & 0.04 & 0.01 & 0.18 \\
\hline Government fractionalisation & 0.46 & 0.24 & 0 & 0.92 & 0.01 & 0.15 & -0.58 & 0.52 & 0.45 & 0.20 & 0.00 & 0.76 \\
\hline Government majority & 0.54 & 0.09 & 0.19 & 0.89 & 0.00 & 0.07 & -0.32 & 0.33 & 0.54 & 0.06 & 0.37 & 0.62 \\
\hline Legislative election & 0.07 & 0.25 & 0 & 1 & 0.00 & 0.25 & -0.09 & 0.95 & 0.07 & 0.01 & 0.05 & 0.09 \\
\hline Left-wing government & 2.55 & 1.49 & 1 & 5 & -0.03 & 1.40 & -2.59 & 3.11 & 2.58 & 0.58 & 1.24 & 3.59 \\
\hline Democratic consolidation & 46.59 & 30.15 & 6 & 137.50 & & & & & 43.00 & 30.23 & 6.61 & 125.88 \\
\hline GDP growth (\%) & 0.47 & 1.35 & -11.49 & 20.86 & -0.10 & 1.32 & -12.54 & 19.51 & 0.57 & 0.30 & 0.01 & 1.35 \\
\hline Inflation (\%) & 0.56 & 1.96 & -22.41 & 32.22 & -0.35 & 2.20 & -23.51 & 31.12 & 0.91 & 1.10 & 0.37 & 5.28 \\
\hline Domestic interest rate (\%) & 2.46 & 2.35 & -0.64 & 16.05 & -1.15 & 2.29 & -10.10 & 10.59 & 3.61 & 1.96 & 2.64 & 10.24 \\
\hline Fiscal deficit (\% of GDP) & -2.91 & 4.85 & -41.80 & 12.20 & 0.02 & 4.40 & -36.56 & 13.94 & -2.94 & 2.04 & -7.33 & 1.17 \\
\hline Public debt (\% of GDP) & 61.48 & 32.50 & 7.80 & 181.20 & 0.38 & 16.78 & -37.55 & 63.27 & 61.10 & 28.30 & 14.07 & 131.67 \\
\hline International reserves (\% of GDP) & 40.06 & 43.05 & 0.53 & 286.69 & 0.35 & 24.82 & -53.63 & 195.92 & 39.70 & 30.17 & 4.76 & 107.29 \\
\hline EMU membership & 0.55 & 0.50 & 0 & 1 & 0.13 & 0.23 & -0.79 & 0.89 & 0.42 & 0.36 & 0.00 & 0.79 \\
\hline
\end{tabular}


Table 2. Political determinants of sovereign bond spreads

\begin{tabular}{|c|c|c|c|c|c|c|}
\hline & \multicolumn{3}{|c|}{$\begin{array}{l}\text { Model 1: Direct } \\
\text { effects }\end{array}$} & \multicolumn{3}{|c|}{$\begin{array}{l}\text { Model 2: Interaction } \\
\text { model }\end{array}$} \\
\hline & B & S.E. & Sig. & B & S.E. & Sig. \\
\hline \multicolumn{7}{|l|}{ Within effects: } \\
\hline Minister of finance change & 1.00 & 0.16 & $* * *$ & 1.85 & 0.29 & $* * *$ \\
\hline Government fractionalisation & 0.59 & 0.24 & $* *$ & 4.90 & 0.49 & $* * *$ \\
\hline Government majority & 4.28 & 0.56 & $* * *$ & 9.34 & 0.96 & $* * *$ \\
\hline Legislative election & 0.10 & 0.18 & & 0.23 & 0.36 & \\
\hline $\begin{array}{l}\text { Left-wing government } \\
\text { Democratic consolidation X Minister of finance }\end{array}$ & 0.13 & 0.02 & $* * *$ & 0.18 & 0.05 & $* * *$ \\
\hline change & & & & -0.02 & 0.01 & $* *$ \\
\hline $\begin{array}{l}\text { Democratic consolidation X Government } \\
\text { fractionalisation }\end{array}$ & & & & -0.07 & 0.01 & $* * *$ \\
\hline $\begin{array}{l}\text { Democratic consolidation X Government } \\
\text { majority }\end{array}$ & & & & -0.08 & 0.02 & $* * *$ \\
\hline Democratic consolidation X Legislative election & & & & 0.00 & 0.01 & \\
\hline government & & & & 0.00 & 0.00 & \\
\hline \multicolumn{7}{|l|}{ Between effects: } \\
\hline Minister of finance change & 5.42 & 1.49 & $* * *$ & 12.40 & 4.30 & $* *$ \\
\hline Government fractionalisation & -1.36 & 0.28 & $* * *$ & 2.07 & 0.75 & $* *$ \\
\hline Government majority & 2.01 & 0.79 & $*$ & 16.70 & 2.11 & $* * *$ \\
\hline Legislative election & 40.47 & 4.56 & $* * *$ & 190.89 & 15.84 & $* * *$ \\
\hline Left-wing government & 0.21 & 0.08 & $*$ & 1.47 & 0.19 & $* * *$ \\
\hline Democratic consolidation & -0.02 & 0.00 & $* * *$ & 0.41 & 0.03 & $* * *$ \\
\hline $\begin{array}{l}\text { Democratic consolidation X Minister of finance } \\
\text { change }\end{array}$ & & & & -0.35 & 0.11 & $* * *$ \\
\hline $\begin{array}{l}\text { Democratic consolidation X Government } \\
\text { fractionalisation }\end{array}$ & & & & -0.09 & 0.02 & $* * *$ \\
\hline $\begin{array}{l}\text { Democratic consolidation X Government } \\
\text { majority }\end{array}$ & & & & -0.19 & 0.04 & $* * *$ \\
\hline Democratic consolidation X Legislative election & & & & -2.81 & 0.30 & $* * *$ \\
\hline $\begin{array}{l}\text { Democratic consolidation X Left-wing } \\
\text { government }\end{array}$ & & & & -0.04 & 0.00 & $* * *$ \\
\hline Constant & -7.60 & 1.09 & $* * *$ & -23.59 & 3.58 & $* * *$ \\
\hline $\mathrm{N}$ (total / countries) & \multicolumn{3}{|c|}{$1564 / 25$} & \multicolumn{3}{|c|}{$1564 / 25$} \\
\hline Model fit (overall) & \multicolumn{3}{|c|}{$1152.58(17.32 \%)$} & \multicolumn{3}{|c|}{1293.49 (+19.44\%) } \\
\hline Model fit (political variables) & \multicolumn{3}{|c|}{$189.36(3.33 \%)$} & \multicolumn{3}{|c|}{$330.27(5.80 \%)$} \\
\hline Time effects & \multicolumn{3}{|c|}{ Yes } & \multicolumn{3}{|c|}{ Yes } \\
\hline Economic controls & \multicolumn{3}{|c|}{ Yes } & \multicolumn{3}{|c|}{ Yes } \\
\hline
\end{tabular}

Note: multilevel regression analyses with one random intercept (country-level); ${ }^{*}=p \leq 0.05 ;{ }^{* *}=p \leq$ $0.01 ; * * *=p \leq 0.001$; the models use Heteroscedasticity and autocorrelation (HAC) robust standard errors 
Figure 3. The effects of minister of finance change on sovereign bond spreads, conditional on democratic consolidation

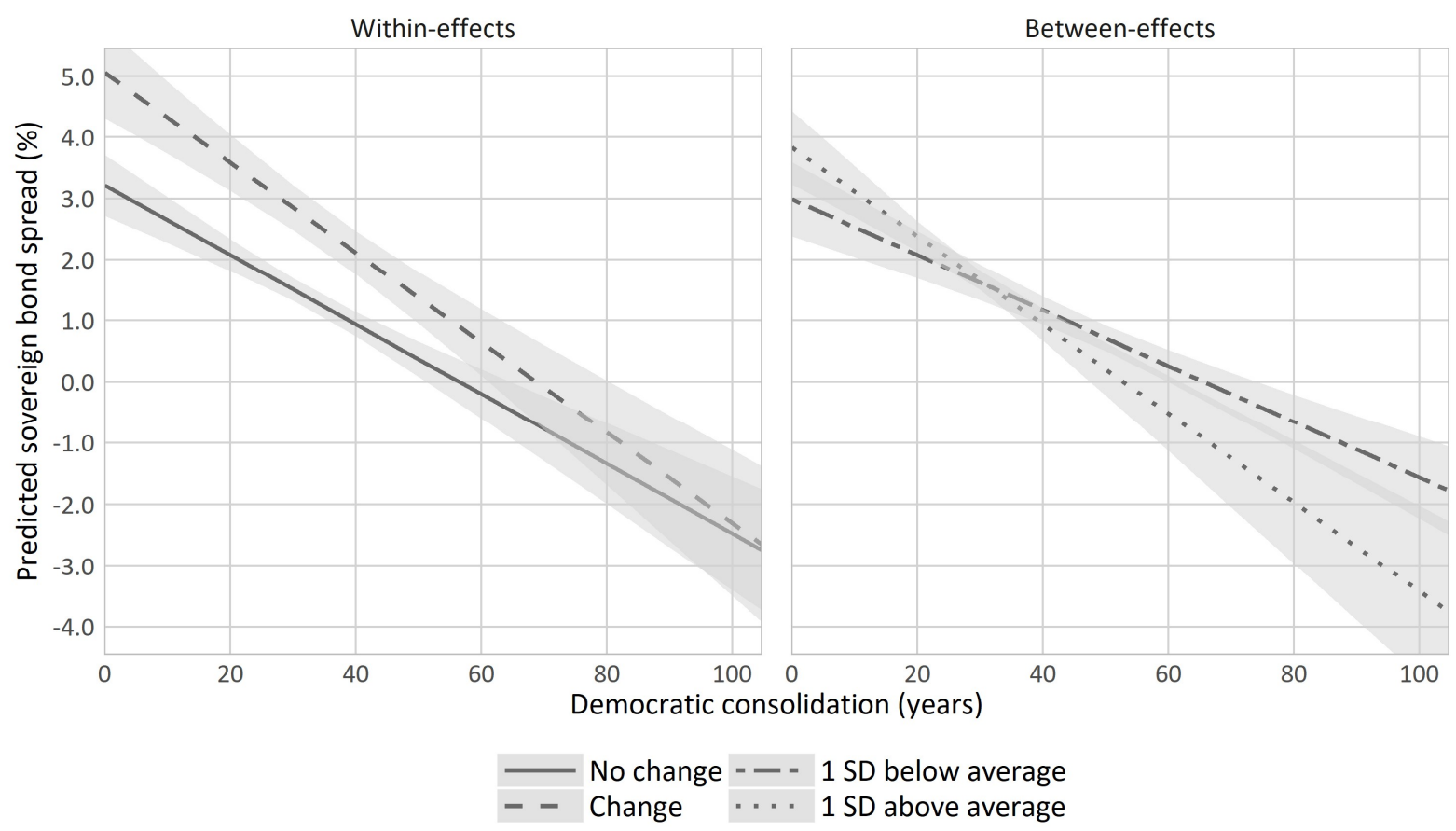


Figure 4. The effects of government fractionalisation on sovereign bond spreads, conditional on democratic consolidation

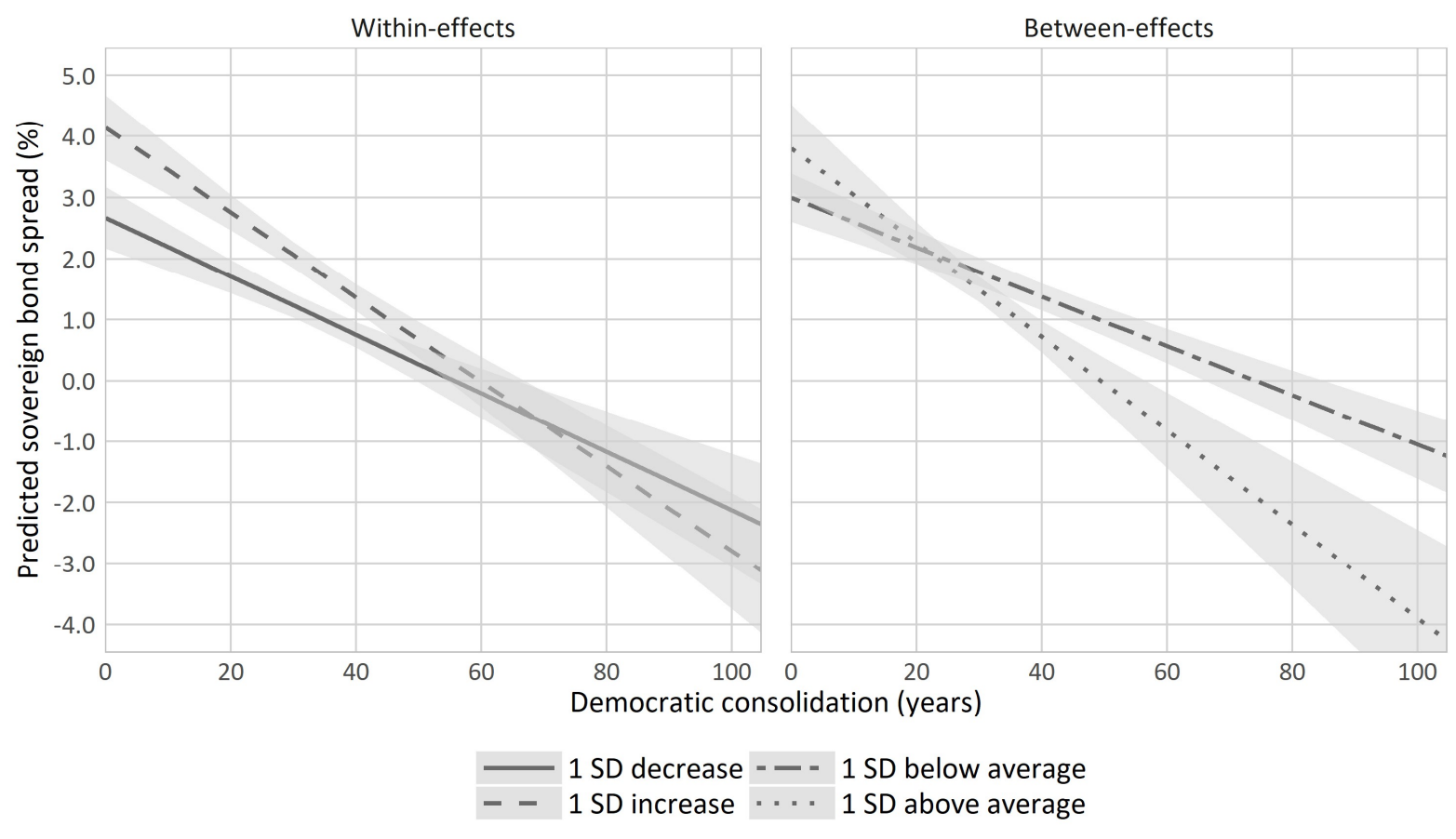


Figure 5. The effects of government majority on sovereign bond spreads, conditional on democratic consolidation

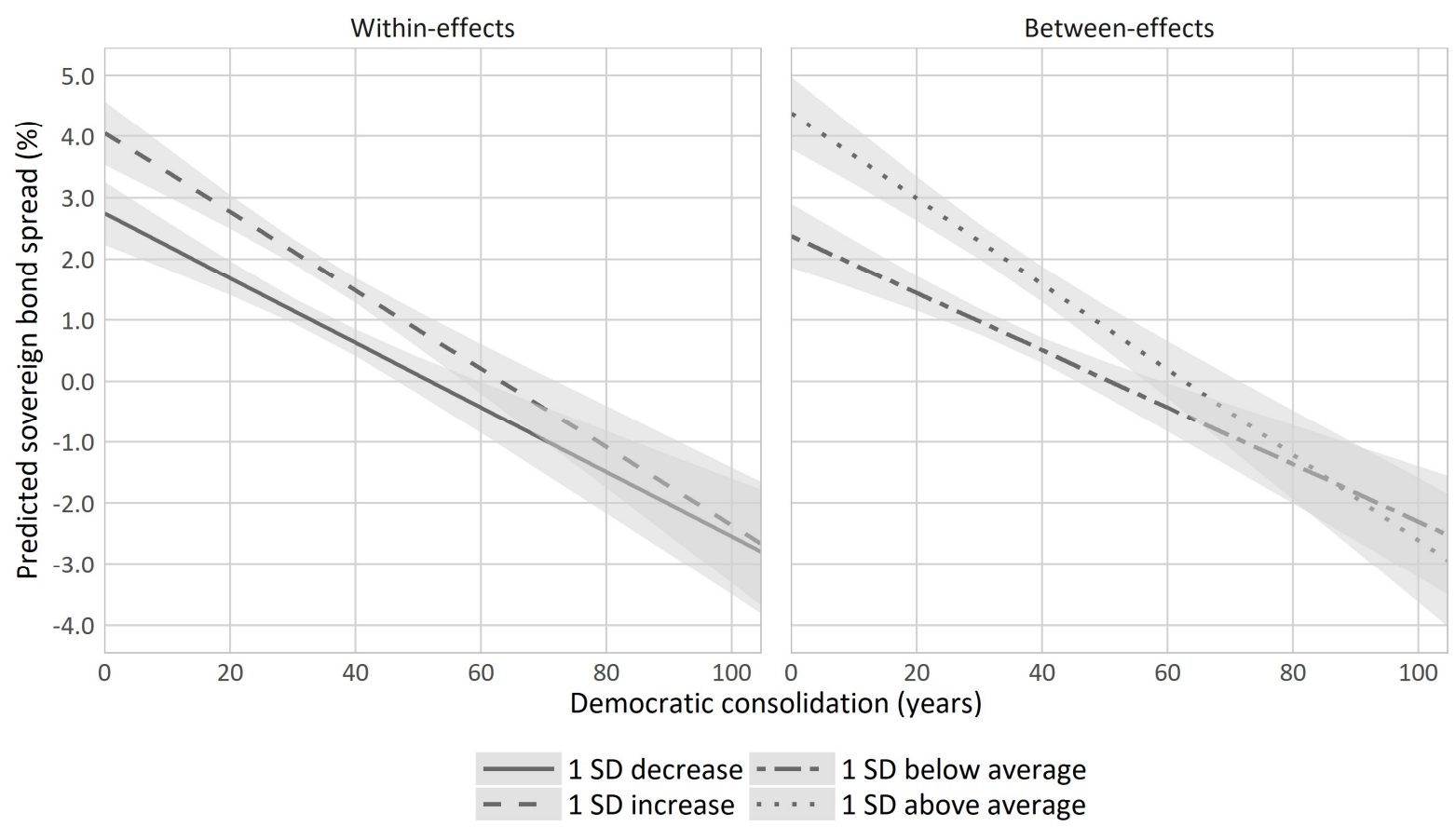


Figure 6. The effects of legislative elections on sovereign bond spreads, conditional on democratic consolidation

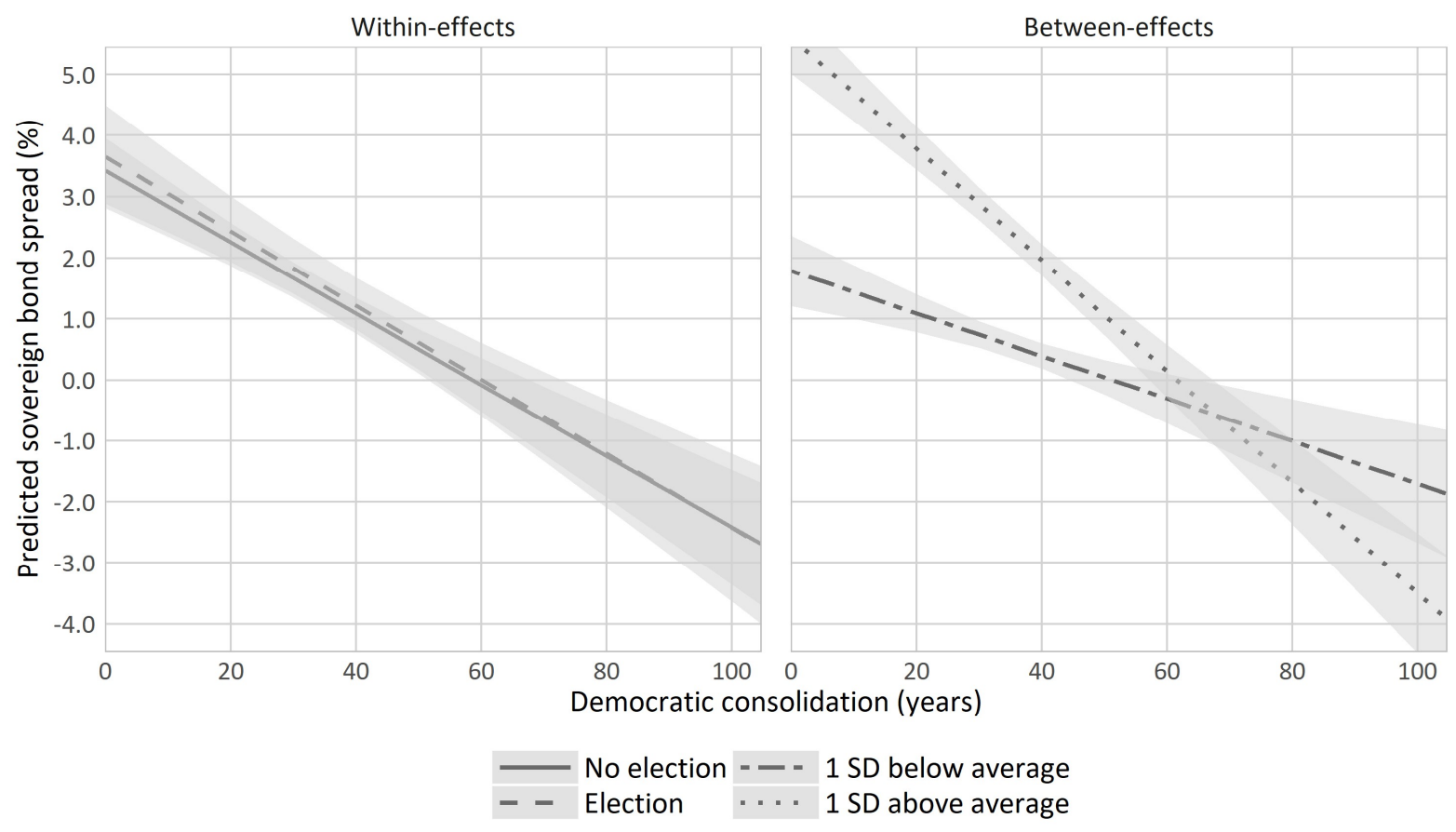


Figure 7. The effects of left-wing governments on sovereign bond spreads, conditional on democratic consolidation

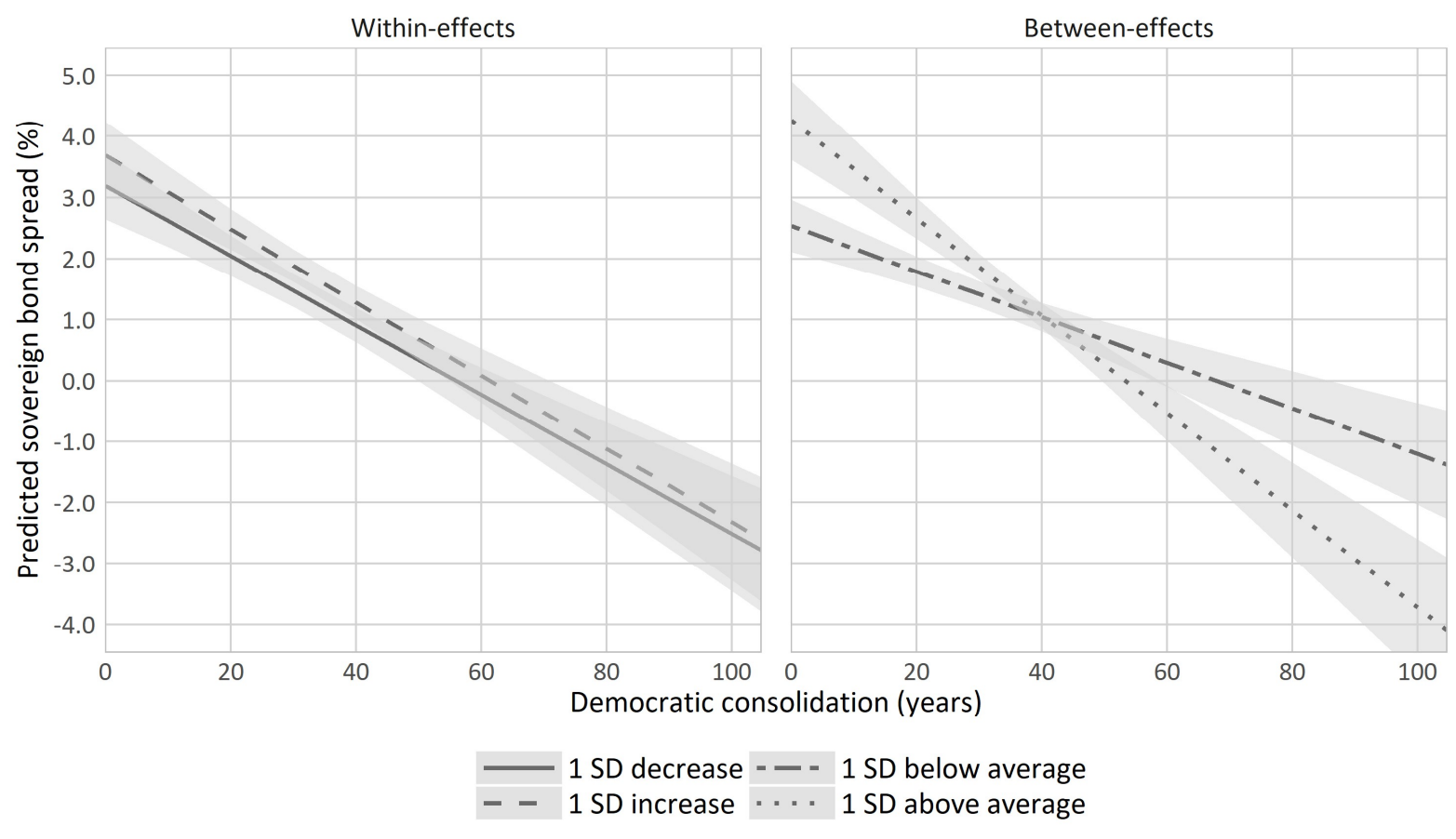


Appendix table 1. Political determinants of sovereign bond spreads (full model results)

\begin{tabular}{|c|c|c|c|c|c|c|}
\hline & \multicolumn{3}{|c|}{$\begin{array}{l}\text { Model 1: Direct } \\
\text { effects }\end{array}$} & \multicolumn{3}{|c|}{$\begin{array}{l}\text { Model 2: Interaction } \\
\text { model }\end{array}$} \\
\hline & B & S.E. & Sig. & B & S.E. & Sig \\
\hline \multicolumn{7}{|l|}{ Within effects: } \\
\hline GDP growth (\%) & -0.48 & 0.04 & $* * *$ & -0.45 & 0.04 & $* * *$ \\
\hline Inflation & -0.04 & 0.03 & & -0.20 & 0.06 & $* * *$ \\
\hline Domestic interest rate & 0.43 & 0.04 & $* * *$ & 0.36 & 0.03 & $* * *$ \\
\hline Fiscal deficit (\% of GDP) & 0.00 & 0.01 & & 0.01 & 0.01 & \\
\hline Public debt (\% of GDP) & 0.06 & 0.00 & $* * *$ & 0.06 & 0.00 & $* * *$ \\
\hline International reserves (\% of GDP) & 0.00 & 0.00 & & 0.00 & 0.00 & + \\
\hline EMU member state & -0.71 & 0.26 & $* *$ & -1.18 & 0.28 & $* * *$ \\
\hline Minister of Finance change & 1.00 & 0.16 & $* * *$ & 1.85 & 0.29 & $* * *$ \\
\hline Government fractionalization & 0.59 & 0.24 & $* *$ & 4.90 & 0.49 & $* * *$ \\
\hline Government majority & 4.28 & 0.56 & $* * *$ & 9.34 & 0.96 & $* * *$ \\
\hline Legislative election & 0.10 & 0.18 & & 0.23 & 0.36 & \\
\hline Leftwing government & 0.13 & 0.02 & $* * *$ & 0.18 & 0.05 & $* * *$ \\
\hline $\begin{array}{l}\text { Democratic consolidation X Minister of Finance } \\
\text { change }\end{array}$ & & & & -0.02 & 0.01 & $* *$ \\
\hline $\begin{array}{l}\text { Democratic consolidation X Government } \\
\text { fractionalization }\end{array}$ & & & & -0.07 & 0.01 & $* * *$ \\
\hline Democratic consolidation X Government majority & & & & -0.08 & 0.02 & $* * *$ \\
\hline Democratic consolidation X Legislative election & & & & 0.00 & 0.01 & \\
\hline Democratic consolidation $X$ Leftwing government & & & & 0.00 & 0.00 & \\
\hline
\end{tabular}




\begin{tabular}{|c|c|c|c|c|c|c|}
\hline & \multicolumn{3}{|c|}{$\begin{array}{l}\text { Model 1: Direct } \\
\text { effects }\end{array}$} & \multicolumn{3}{|c|}{$\begin{array}{l}\text { Model 2: Interaction } \\
\text { model }\end{array}$} \\
\hline & B & S.E. & Sig. & B & S.E. & Sig. \\
\hline \multicolumn{7}{|l|}{ Between effects: } \\
\hline GDP growth (\%) & 1.40 & 0.22 & $* * *$ & -0.22 & 0.29 & \\
\hline Inflation & 0.07 & 0.06 & & -0.19 & 0.08 & $*$ \\
\hline Domestic interest rate & 0.37 & 0.03 & $* * *$ & 0.52 & 0.04 & $* * *$ \\
\hline Fiscal deficit (\% of GDP) & -0.01 & 0.04 & & 0.40 & 0.09 & $* * *$ \\
\hline Public debt (\% of GDP) & 0.03 & 0.00 & $* * *$ & 0.04 & 0.01 & $* * *$ \\
\hline International reserves (\% of GDP) & 0.00 & 0.00 & & -0.04 & 0.01 & $* * *$ \\
\hline EMU member state & -0.83 & 0.31 & $* *$ & -2.42 & 0.69 & $* * *$ \\
\hline Minister of Finance change & 5.42 & 1.49 & $* * *$ & 12.40 & 4.30 & $* *$ \\
\hline Government fractionalization & -1.36 & 0.28 & $* * *$ & 2.07 & 0.75 & $* *$ \\
\hline Government majority & 2.01 & 0.79 & $*$ & 16.70 & 2.11 & $* * *$ \\
\hline Legislative election & 40.47 & 4.56 & $* * *$ & 190.89 & 15.84 & $* * *$ \\
\hline Leftwing government & 0.21 & 0.08 & $*$ & 1.47 & 0.19 & $* * *$ \\
\hline Democratic consolidation & -0.02 & 0.00 & $* * *$ & 0.41 & 0.03 & $* * *$ \\
\hline $\begin{array}{l}\text { Democratic consolidation X Minister of Finance } \\
\text { change }\end{array}$ & & & & -0.35 & 0.11 & $* * *$ \\
\hline $\begin{array}{l}\text { Democratic consolidation X Government } \\
\text { fractionalization }\end{array}$ & & & & -0.09 & 0.02 & $* * *$ \\
\hline $\begin{array}{l}\text { Democratic consolidation X Government } \\
\text { majority }\end{array}$ & & & & -0.19 & 0.04 & $* * *$ \\
\hline Democratic consolidation X Legislative election & & & & -2.81 & 0.30 & $* * *$ \\
\hline $\begin{array}{l}\text { Democratic consolidation X Leftwing } \\
\text { government }\end{array}$ & & & & -0.04 & 0.00 & $* * *$ \\
\hline Constant & -7.60 & 1.09 & $* * *$ & -23.59 & 3.58 & $* * *$ \\
\hline $\mathrm{N}$ (total / countries) & \multicolumn{3}{|c|}{$1564 / 25$} & \multicolumn{3}{|c|}{$1564 / 25$} \\
\hline Model fit (overall) & \multicolumn{3}{|c|}{$1152.58(17.32 \%)$} & \multicolumn{3}{|c|}{$1293.49(+19.44 \%)$} \\
\hline Model fit (political variables) & \multicolumn{3}{|c|}{$189.36(3.33 \%)$} & \multicolumn{3}{|c|}{330.27 (5.80\%) } \\
\hline Time effects & \multicolumn{3}{|c|}{ Yes } & \multicolumn{3}{|c|}{ Yes } \\
\hline
\end{tabular}

Note: multilevel regression analyses with one random intercept (country-level); ${ }^{\dagger}=p \leq 0.10 ;{ }^{*}=p \leq$ $0.05 ;^{* *}=p \leq 0.01 ; * * *=p \leq 0.001$; the models use Heteroscedasticity and autocorrelation (HAC) robust standard errors 